\title{
Janet Frame: Introduction
}

\section{Marta Dvorak and Christine Lorre}

\section{(2) OpenEdition}

1 Journals

Electronic version

URL: https://journals.openedition.org/ces/7999

DOI: $10.4000 /$ ces.7999

ISSN: 2534-6695

\section{Publisher}

SEPC (Société d'études des pays du Commonwealth)

\section{Printed version}

Date of publication: 1 April 2011

Number of pages: 6-9

ISSN: 2270-0633

\section{Electronic reference}

Marta Dvorak and Christine Lorre, "Janet Frame: Introduction", Commonwealth Essays and Studies [Online], 33.2 | 2011, Online since 18 November 2021, connection on 06 January 2022. URL: http:// journals.openedition.org/ces/7999 ; DOl: https://doi.org/10.4000/ces.7999

\section{(c) (1) (9)}

Commonwealth Essays and Studies is licensed under a Licence Creative Commons Attribution - Pas d'Utilisation Commerciale - Pas de Modification 4.0 International. 


\section{Introduction}

Recent publications by Janet Frame (posthumous) and on Janet Frame have galvanized attention on a writer whose remarkable craft had long been overshadowed on the international scene by an antipodean but expatriate literary predecessor on the one hand and a fascinating life, stuff of romance, on the other. This volume of essays by renowned international scholars, like the recent ground-breaking book, Frameworks, engages with the author's brilliantly skilful writing practices, and extends the undertaking of grappling with the question, "how does Frame's work work?" (Cronin xvi). This issue innovates on another plane by privileging Frame's significant body of short fiction, which, compared to her novelistic production, has till now received relatively scant critical attention.

Frame has been situated at the intersections of postcolonialism, modernism, and postmodernism. Her earliest published collection of short fiction, The Lagoon: Stories (1951, retitled a decade later), can actually be considered to illustrate the staggering of dominant and peripheral modernisms, coterminous with early and late modernisms. Frame's stories (and poems) do of course proclaim the existence of the edge in a postcolonial strategy of locatedness (which erupts on the second page of her posthumous autobiographical novel, Towards Another Summer, in her search for the Southern Cross constellation in English skies) and performance of reinscription, sign of agency and identity (Bhabha 231). She who has lived near "real rivers" as opposed to "English puddles" experiences the jarring gap between reality and representation, being unable to "sit humbly, politely, by a narrow stream beside a bill and afterwards write home about her visit to a river near a mountain" (Frame Summer, 49-50, emphasis added). The protest of the periphery is clearly encapsulated in the first line of the poem "When the Kea Speaks from the Dunedin Botanical Gardens" in which the antipodean position is presented as upside down and therefore wrong: "I have learned to walk upside down like a fly" (Frame Pocket Mirror, 211). Frame's very descriptions are both ontological and political acts, for, as Salman Rushdie remarks, "redescribing the world is the necessary first step towards changing it" (14). Yet as sundry cultural geographers and literary critics - among whom we find some of this issue's contributors - have shown, the paradigms of space and place intersect with writing and reading practices. Insular England remained medieval when the Renaissance was already unfurling in Italy, and art nowveau arrived in postcolonial spaces when art deco had already replaced it in the metropolises of Europe. The expatriate short story writer from New Zealand, Katherine Mansfield, participated in the early/dominant modernist movement of thought which unfurled in Europe in the first two decades of the twentieth century, mixing with other avant-garde writers like her ally and rival Virginia Woolf. The late modernism of Janet Frame, born barely before Mansfield died, arguably overlaps with the postmodernism beginning to unfurl in Great Britain and the United States. But, as it does with Australia's Patrick White (The Tree of Man, 1955) and Canada's expatriate master of the short story genre, Mavis Gallant, Frame's late modernism co-exists with the late works of early modernists such as Ernest 
Hemingway's The Old Man and the Sea (1952), and it also cohabits with the modernist art scene still at its height in California, where, in congruence with Frame's fascination with perception, visual artists exploring and stretching the structure of seeing, like Marc Chagall, Fernand Léger, and Max Ernst, continued to exhibit widely.

In New Zealand, the arrival of modernism coincided with a period of literary nationalism. Stuart Murray talks of a "particular version of settler modernity" (16) to refer to the literary movement that started in the 1930s and that had coalesced by the mid-1940s, leading to a new cultural awareness that consisted simultaneously in cultural nationalism (concurring with the 1940 centennial) and an interest in models and ideas from abroad to express a sense of cultural difference (Murray 13, 30). Lawrence Jones points out that, apart from Robin Hyde, women were absent from the movement, and talks of its "literary mysogyny" (425). In this respect, the publication of Frame's Lagoon stories by the Caxton press, which played a crucial role in the development of a New Zealand national literature, signaled the emergence of an important new voice. Frame was awarded the Commonwealth Writers' Prize only after four decades of publishing (1989), and her prolific production can moreover be seen to illustrate the manners in which post/modernism follows after and prolongs modernism (without of course denying its strategies of demarcation). As many of this volume's contributors point out, the earlier short stories anticipate the concerns and stratagems of the later postmodern novels, which assume a more overtly metatextual approach in which the theory not only underpins the fiction but catalyzes it.

The twelve essays of this issue simultaneously cover varied ground and share a number of recurring concerns about Frame's short fiction, starting with The Lagoon. All the contributors, in one way or another, acknowledge the "rich excess of meaning" of Frame's texts and "the hermeneutic diligence and openness which reading Frame" requires, in Mark Williams's words (67). This necessary openness entails that most of the essays do not deal exclusively with one potentially narrow aspect of Frame's writing, but offer multiple entries into it.

Frame's first collection of short fiction "continuously addresses the subject of words," W. H. New points out in this volume as he engages with the writer's "rhetoric of identity" (39). Marc Delrez examines the author's strategies of literal representation, linked with her ubiquitous sense of humour, and focuses on how she exploits dead metaphors to expose the dialectical relationship between truth and invention. As the translators of The Lagoon into French, Jean Anderson and Nadine Ribault were confronted with a number of challenges to be solved. How is one to translate the author's distinctive voices in words that are not hers? To render the nuances of meaning linked to time and space, namely to the period aspects of The Lagoon and to New Zealand culture? To transmute the inventiveness of Frame's poetic style? W.H. New reads The Lagoon as a collection of stories about words, and explores how the latter can "clothe identity in definition" and "disclose the limits of definition" as part of what he calls Frame's "rhetoric of identity" (39).

Several essays engage with and take a step beyond the "unhelpful dichotomy" that has led to a "critical divide" (56-58) between critics who see Frame primarily as a realist or an imaginative writer, a writer of autobiography or of fiction, etc. Allan Weiss places Frame's short fiction in the context of fantastic literature in general to assess the extent to which she is not a social-realist writer, concluding that she writes 
modern fables that combine fantasy and social concerns. Lydia Wevers considers the interaction between Frame's autobiography and her fiction in the light of Patrick Evans's recent novel, Gifted, to suggest that readers should stop trying to fit Frame into a single discursive frame and to demonstrate that "the power of the ' $\mathrm{T}$ ' writer is always at issue and the 'I' persona is always in question" (62). Mark Williams analyzes a number of ethical issues related to the violences of colonization that are discreetly brought up in The Lagoon through Frame's subtle strategies of reader involvement. This firmly anchors her fiction in the processes of imagining the nation. John Thieme studies images of land and sea in "The Lagoon" and Faces in the Water to underline how Frame collapses the borderline between physical and psychic geographies and dismantles conventional conceptions of time and place, turning the story into a fluid medium.

The definition and apprehension of the self are central to Frame's short fiction. Christine Lorre investigates the secrets of The Lagoon in the light of Jacques Derrida's ideas as a way into Frame's urge to describe the self in transcendent terms. She concludes that secrets in Frame's stories always retain a core that cannot be explained, and that makes up the inner self. Simone Oettli studies the self as writer in three key stories in The Lagoon which are specifically about the writing process, focusing on Frame's strategies of projecting multiple selves. She links the metatextual stories to the image of the envoy from Mirror City which Frame subsequently developed in her autobiography, positing that Romanticism and neo-Platonism are the defining traits of Frame's vision of the writer. Cindy Gabrielle analyzes how the boundaries - or "fences of being" - that either define or fail to define identity, especially children's, shape early on the relationship of the self to others and to death. She approaches Frame's short fiction through Buddhist wisdom, which emphasizes the non-dual nature of reality, to demonstrate that in Frame's view the absence of boundaries is a preferable condition.

Frame's rich metafictional pieces have garnered attention in the study of her storytelling techniques. Janet Wilson discusses Frame's strategies of reversal and indirection in "The Lagoon," "Jan Godfrey" and "My Last Story," showing how the narrator repositions herself in these metafictional narratives on the art of storytelling. Marta Dvorak evaluates how Frame's writing transforms storytelling into stories about telling - as such, the antipodean writer's stories are part of the radical transformation underpinning the whole of modernist production. She demonstrates how Frame uses various forms of metalepsis (or frame-breaking) to create disruptions that entrench the control of her strong authorial presence and lead to constraints in the writing and reading processes

Marta DVORAK and Christine LORRE 


\section{Works Cited}

BHABHA, Homi. The Location of Culture. London: Routledge, 1994.

Cronin, Jan, and Simone Drichel, eds. Frameworks: Contemporary Criticism on Janet Frame. Amsterdam: Rodopi, 2009.

Frame, Janet. Janet Frame stories and poems. The Lagoon \& Other Stories/The Pocket Mirror. Auckland: Vintage, 2004.

—. Towards Another Summer. London: Virago Press, 2008.

JONES, Lawrence. Picking Up the Traces: The Making of a New Zealand Literary Culture 1932-1945. Wellington: Victoria University Press, 2003.

Murray, Stuart. Never a Soul at Home: New Zealand Literary Nationalism and the 1930s. Wellington: Victoria University Press, 1998.

RusHDIE, Salman. Imaginary Homelands. London: Granta, 1992. 